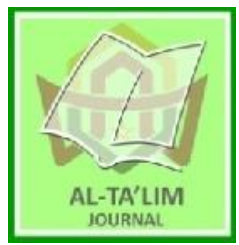

AL-TA'LIM JOURNAL, 27 (1), 2020, (30-40)

(Print ISSN 1410-7546 Online ISSN 2355-7893)

Available online at http://journal.tarbiyahiainib.ac.id/index.php/attalim

\title{
The Development of Statistics Modules for the Students of Islamic Colleges and Universities in South Tapanuli
}

\author{
Received: $05^{\text {th }}$ April 2019; Revised: $06^{\text {th }}$ April 2019; Accepted: $27^{\text {th }}$ February 2020 \\ Permalink/DOI: https://doi.org/10.15548/jt.v27i1.604
}

\section{Ahmad Nizar Rangkuti*) \\ Institut Agama Islam Negeri \\ Padangsidimpuan, Indonesia \\ E-mail:nizarahmad1304@yahoo.com}

\section{Latifa Annum Dalimunthe \\ Institut Agama Islam Negeri \\ Padangsidimpuan, Indonesia \\ E-mail:latifaannum@gmail.com}

\section{Ali Asrun Lubis \\ Institut Agama Islam Negeri \\ Padangsidimpuan, Indonesia \\ E-mail: asrunali@gmail.com \\ *) Corresponding Author}

\begin{abstract}
This study aims to develop a statistical module for the students of Islamic colleges and universities in South Tapanuli. Research and Development (R\&D) with Instructional Development Institute (IDI) model was implemented. This research consists of three stages, namely, the front-end analysis stage, the prototype stage, and the assessment stage. The results of the study showed that the statistical module that was designed was valid including content validity and construct. The result also showed the use of statistical modules in the learning process does not experience significant obstacles, in the practical sense of their use according to the assessments of observers and students and lecturers. It indicated that the statistical module has been effective which is shown from the results of observations on the implementation of the learning process, the results of interviews with lecturers and students, as well as higher student learning outcomes using modules in learning.
\end{abstract}

Keywords: Module; statistics; valid; practical; effective learning

How to Cite: Rangkuti, A., Dalimunthe, L., \& Lubis, A. (2020). The Development of Statistics Modules for the Students of Islamic Colleges and Universities in South Tapanuli. Al-Ta lim Journal, 27(1). doi:https://doi.org/10.15548/jt.v27i1.604

\section{INTRODUCTION}

The learning process in general is conventionally held by utilizing teaching materials and classroom techniques; however the learning process assisted with certain modules is proven to be more effective. The learning process with modules would significantly improve the scientific process of the learning and students' attitude for the science courses (Marsan, et.al., 2016). In fact, the real condition shows that the textbooks, especially the available Statistics book, in general, have not yet facilitated students to construct their own knowledge. The description presented in the Statistics book tends to be in the form of plain texts, without further understanding that provided the benefits for the learning process. Also, the teaching materials are unlikely not-related to the useful statistics equations in the real world.

Documentation studies on the value of statistics courses in several study programs show that the final grades of the students are still not satisfactory. Nevertheless, it was found that there were phenomena which show that many students in their final semester were less interested in doing quantitative research and were more likely to conduct qualitative research for their final thesis. This condition is somehow related to the lectures on statistics courses for not producing the acceptable quality in the learning process. In conclusion, it is necessary to develop a module as a companion book in statistics courses. Module 
is a teaching material that is designed systematically and allows to be studied independently to master the expected competencies (Darmiyatun, 2013; Purwanto, et.al., 2007; Prastowo, 2010). The learning process with modules aims to enable students to study independently with a little help from lecturers (Prastowo, 2010). As a teaching material, module in talks is also useful for an independent use. Johnson (2008) stated that through independent learning, the module will give the students the freedom to find their own understandings of certain academic subjects.

Teaching material is an important part in the learning process (Yani, 2012). Ajoke (2017), and Olumorin, et.al. (2010) added that teaching material is an important tool needed in the learning process for teacher in teaching efficiency and improving student performance. The development of teaching materials has a positive impact in increasing student competency (Gusmania \& Pamungkas, 2015; Hanggara \& Amelia, 2018; Agustyaningrum \& Gusmania 2017; Maulydia et.al., 2017; and Husna \& Himmi, 2018).

Dahar (2011) recommends that students study independently to find their own concepts. By using modules, students can continue the next material if the material in the module has been mastered. On the contrary, if students have not mastered the material, they will be asked to repeat the teaching material. Thus students can study independently to improve their own abilities (Daryanto, 2002). With the course modules, the learning system will open more opportunities for students to construct or build their knowledge in accordance with their own preferences. Statistics are a part of mathematics that has an important role in life (Ashaari, et al., 2011). Statistics is one of the compulsory courses in every study program at the undergraduate level. The benefits of studying statistics include conducting data processing and analysis in quantitative research. Statistics is included as an important subject because of the importance of conducting research as the final project for all study programs in every discipline available in Islamic colleges and universities. The learning process should include the development of concepts, exercises in problem solving which include the use of concepts. The role of the lecturer is more likely to be as a facilitator, and a supervisor. Lecturers encourage students to learn statistics with fun. Thus, a statistical module is needed.

\section{METHODS}

This type of this research is development research, by adopting the steps implemented by Nisiyatussani, et al (2018), which consists of needs analysis, module design, module development, expert testing, field testing in the natural place of the product to be used, in practice applying the division of students into small groups as suggested by Oktiningrum, et al (2016); and prototype. The research was conducted in the Madrasah Ibtidaiyah of Teacher Education Program in IAIN Padangsidimpuan and in the Islamic Education Program of STAIN Mandailing Natal in the odd semester of the academic year 2019/2020.

\section{Front-end Analysis}

At this stage, an analysis of statistical material is conducted by reviewing the literature related to the learning modules, interviewing statistics lecturers and peers, and studying the characteristics of the students of Islamic colleges and universities (PTKIN).

\section{Prototyping Phase}

Based on the results of the back-to-front analysis, the next step is to design the prototype statistics module teaching materials. The prototype phase is conducted in two stages, namely the validation stage and the practicality stage (Yansen, 2019; Hamdunah, 2016; and Muttaqin, 2017). The validation phase is conducted for lecturers who have competence in the field of statistics by conducting discussions and interviews in connection with the designed statistical modules (Nizar, 2018; and Sagita, 2018). Furthermore, the design was given to five validators. The validation process is done by giving validation sheets to the five validators. 


\section{Data Collection Technique}

The data in this study were collected through various sources i.e. several experts, from students, observers, and assessments from five competent validators (statistics lecturers and experienced peer lecturers), using observation, interview and test instruments.

\section{Data Analysis Techniques}

Validity analysis is done by analyzing all aspects assessed by the five validators of the module components. The analysis is presented in tabular form to determine the percentage of validity. Qualitative data were analyzed descriptively, and quantitative data were analyzed quantitatively. The module validity data was obtained from the results of the validation conducted by five validators. The collected data is then tabulated. The results of the tabulation are searched for the percentage by the formula:

$$
\mathrm{P}=\frac{\sum \text { score per item }}{\text { maximum score }} \times 100 \%
$$

To see the validity categories described in the following table 1 .

Table 1. The Validity Category of the Statistics Module

\begin{tabular}{ll}
\hline Percentage & Category \\
\hline $0-20$ & Not valid \\
$21-40$ & Less Valid \\
$41-60$ & Fairly Valid \\
$61-80$ & Valid \\
$81-100$ & Very Valid \\
\hline
\end{tabular}

Descriptive techniques are used to describe data from the prototype validation discussion with the statistics lecturer.

\section{RESULT AND DISCUSSION}

This research was conducted at the Islamic Education Study Program of Madrasah Ibtidaiyah IAIN Padangsidimpuan and in the Islamic Religious Education Study Program of STAIN Mandailing Natal in Statistics. The stages carried out in this study are a front-end analysis of the activities including curriculum analysis of statistical courses, learning outcomes of statistical courses, followed by a prototyping phase by designing a statistics module and assessment phase described as follows.

\section{The Results of Front-end Analysis}

This statistics module is designed based on a front-end analysis consisting of analysis of statistics textbooks, reviewing the module, interviewing statistics lecturers, interviewing students, and studying the characteristics of the students of Islamic colleges and universities (PTKIN).The material developed in the module is the result of analysis based on syllabus and Semester Lesson Plan of statistics courses at IAIN Padangsidimpuan and STAIN Mandailing Natal. The principle of developing this module material refers to statistical material which is the core material of overall statistics. In addition, the principle of effectiveness in the use of time is also a concern of researchers in designing this module. Here, the statistical material is very broad, so researchers choose material that is very urgent in studying statistics.

The purpose of studying the characteristics of students is to determine the general ability of students about statistics. At this stage, the interviews with statistics lecturers and document analysis are conducted. The document in question is a list of student results, especially for statistics subject. The module characteristics developed are based on modifications between the module characteristics described by Kemp (1994) and the characteristics of the modules developed by Joni \& Wardhani (1984). The characteristics of the modules in question are: material/framework identity, introduction, learning objectives, instructional instructions, description of learning content, summary, reading sources, and practice questions and answer keys. The statistics module that has been designed is then being consulted with the validators for design and content for 3 weeks. After, the draft was being revised according to validators' suggestion, and then the design is considered as the initial prototype. 


\section{Results of Prototype/Module Validity}

After the critics, suggestions, and input from the validators were obtained, then the prototype was discussed with the validators and the prototype was subsequently revised according to the suggestions. The questionnaire data from the validators' assessment was described and analyzed qualitatively and quantitatively. The validation process was conducted by following three design/construct validators and two statistics content validators. The design of the learning kit was revised according to comments and suggestions from the design validators and content experts. The revised results of the design became the initial prototype.

\section{Advices from Design Validators}

Based on the design validators' suggestion, there are some parts of the module's organizational design that must be improved. The revisions suggested by the validators in detail can be seen in table 2 below.

Table 2.Revised List of Design Validators

\begin{tabular}{|c|c|}
\hline Validated aspects & Suggestions \\
\hline Cover and binding & $\begin{array}{l}\text { An interesting cover can represent the contents of the module in general, } \\
\text { especially in the form of images }\end{array}$ \\
\hline Material content framework & The module material is made sequentially \\
\hline Preliminary & Preliminary writing is designed to be more interesting \\
\hline Instructions for learning & Learning instructions are made according to needs \\
\hline Learning objectives & Added special purpose indicators based on general objectives. \\
\hline Learning Content Description & The example is already in the material description \\
\hline Summary & Information should be compressed in summary \\
\hline Practice questions and answer keys & $\begin{array}{l}\text { The title of the questions and answers are designed as attractive as } \\
\text { possible }\end{array}$ \\
\hline Reading source & - \\
\hline
\end{tabular}

\section{Advices from Content Validators}

Based on individual tests of the content validators, there are several parts of the module organization content that must be corrected. The revisions suggested by the validators in detail can be seen in the following Table 3 .

Table 3.Revision List of Content Validators

\begin{tabular}{ll}
\hline \multicolumn{1}{c}{ Validated aspects } & \multicolumn{1}{c}{ Suggestions } \\
\hline Material content framework & $\begin{array}{l}\text { Add a description of simple linear regression material } \\
\text { Pdeliminary }\end{array}$ \\
& $\begin{array}{l}\text { Adjust the introductory directions according to the material in } \\
\text { accordance with the discussion of each module }\end{array}$ \\
Instructions for learning & Need to be clarified and reinforced learning instructions \\
Learning objectives & Adjust the learning objectives with the material in the module \\
Learning Content Description & Repaired the flow is still not appropriate \\
Summary & Use language that is easily understood by students \\
Practice questions and answer keys & The contents are compacted. \\
Reading source & Variations in practice questions were revised to meet C6 aspects \\
\hline
\end{tabular}

\section{Final Validation Results from the Design/Construct Validators}

After all the suggestions from the validators both design and content validators and from the supporting lecturers and students from the test, the module is assessed by the validators to determine the level of module validation. The aspects validated by the design/construct validators are aspects of module organization, writing format, use of language and illustrations/drawings. Broadly 
speaking, the module organization validation, writing format, language use and illustrations/images can be seen in Table 4 below.

Table 4.Construct Validation Questionnaire Results Data

\begin{tabular}{|c|c|c|c|c|c|}
\hline \multirow{2}{*}{ Evaluated Aspect } & \multicolumn{3}{|c|}{ Validators } & \multirow{2}{*}{ Total } & \multirow{2}{*}{$(\%)$} \\
\hline & 1 & 2 & 3 & & \\
\hline Cover and binding & 46 & 46 & 49 & 141 & 85.45 \\
\hline $\begin{array}{l}\text { Material content } \\
\text { framework }\end{array}$ & 49 & 50 & 50 & 149 & 90.30 \\
\hline preliminary & 50 & 48 & 48 & 146 & 88.48 \\
\hline Learning objectives & 42 & 45 & 44 & 131 & 79.39 \\
\hline $\begin{array}{l}\text { Practice questions and } \\
\text { answer keys }\end{array}$ & 46 & 48 & 48 & 142 & 86.06 \\
\hline Summary & 49 & 48 & 48 & 145 & 87.88 \\
\hline $\begin{array}{l}\text { Instructions for } \\
\text { learning }\end{array}$ & 48 & 47 & 48 & 143 & 86.67 \\
\hline Reading source & 48 & 48 & 48 & 144 & 87.27 \\
\hline $\begin{array}{l}\text { Text / format } \\
\text { identified }\end{array}$ & 47 & 49 & 47 & 143 & 86.67 \\
\hline $\begin{array}{l}\text { Numbered pages and } \\
\text { exercises }\end{array}$ & 47 & 49 & 49 & 145 & 87.88 \\
\hline Ease of use & 48 & 47 & 48 & 143 & 86.67 \\
\hline $\begin{array}{l}\text { Use the appropriate } \\
\text { letter }\end{array}$ & 47 & 47 & 49 & 143 & 86.67 \\
\hline Letters for students & 47 & 45 & 46 & 138 & 83.64 \\
\hline $\begin{array}{l}\text { Physical compatibility } \\
\text { module }\end{array}$ & 46 & 47 & 46 & 139 & 84.24 \\
\hline $\begin{array}{l}\text { Attractive illustration } \\
\text { for students }\end{array}$ & 49 & 47 & 48 & 144 & 87.27 \\
\hline Total & & & & 2136 & \\
\hline
\end{tabular}

Note: The maximum score for each aspect evaluated is 165. The overall maximum score for construct validation is 2475 .

The results of the evaluation of the module organizational design validators, the writing format, the use of language and the illustrations/images that have been developed have referred to the requirements for developing a good module that is cover and binding are good, writing the contents of the material framework is appropriate, preliminary writing has led the reader to the purpose of the module, the learning objectives are correct, the practice questions and answer keys are correct as a means of evaluating the learning objectives, and the proper summary summarizes the material and draws the reader's attention. Learning instructions can be categorized as being able to give signs to the reader so that it makes it easier to learn modules, adequate reading resources as a basis for further development for the reader. The pages and exercises are numbered completely, type and font size and physical size of the module are suitable for student size, and the existing illustrations can attract students' attention in learning the module.

The total score of the design validation questionnaire for the organization of the module, writing format, use of language and illustrations/drawings by the validators totaled 2135. Based on the total score included in the interval class (2113-2640), the module organization, writing format, use of language and illustrations/the overall picture includes very valid criteria. Means the results of the validators' assessment of the module organization, writing format, use of language and illustrations/drawings are correct and can be used with a little revision. The revision suggested by the validators is binding, and the use of operational words in writing special learning objectives.

\section{Final Validation Results from the Content Validator}

After all suggestions from all validators, the module is assessed by the content validators to determine the level of module content validation. The aspects validated by the content validators are the organizational aspects of the module, the writing format, the use of language, illustrations/images, as well as the material translation aspects. Aspects of the elaboration of the material include conformity to the learning objectives, conformity of the learning flow, conformity to the curriculum, conformity with the syllabus, containing all the information needed. Questionnaire data from the validators' assessment of the module organization can be seen in Table 5 below. 
Ahmad Nizar Rangkuti, Latifa Annum Dalimunthe, Ali Asrun Lubis, The Development of... | 35

Table 5.Data Results of the Content Validation Questionnaire

\begin{tabular}{|c|c|c|c|c|}
\hline \multirow{2}{*}{$\begin{array}{l}\text { Evaluational aspects } \\
\text { Material content framework }\end{array}$} & \multicolumn{2}{|c|}{ Validators } & \multirow{2}{*}{$\begin{array}{c}\text { Total } \\
100\end{array}$} & \multirow{2}{*}{$\begin{array}{l}(\%) \\
90.91\end{array}$} \\
\hline & 50 & 50 & & \\
\hline Preliminary & 50 & 49 & 99 & 90.00 \\
\hline Learning objectives & 46 & 44 & 90 & 81.82 \\
\hline Practice questions and answer keys & 52 & 48 & 100 & 90.91 \\
\hline Summary & 48 & 48 & 96 & 87.27 \\
\hline Instructions for learning & 44 & 46 & 90 & 81.82 \\
\hline Reading source & 48 & 49 & 97 & 88.18 \\
\hline Text / format identified & 48 & 51 & 99 & 90.00 \\
\hline Numbered pages and exercises & 47 & 52 & 99 & 90.00 \\
\hline Ease of use & 48 & 49 & 97 & 88.18 \\
\hline Use the appropriate letter & 47 & 50 & 97 & 88.18 \\
\hline Letters for students & 47 & 45 & 92 & 83.64 \\
\hline Physical compatibility module & 48 & 46 & 94 & 85.45 \\
\hline Attractive illustration for students & 48 & 46 & 94 & 85.45 \\
\hline Compliance with objectives & 47 & 45 & 92 & 83.64 \\
\hline Conformity with the learning flow & 49 & 51 & 100 & 90.91 \\
\hline Compliance with the curriculum & 49 & 50 & 99 & 90.00 \\
\hline Contains all required information & 47 & 46 & 93 & 84.55 \\
\hline Enables intertwining between modules & 47 & 46 & 93 & 84.55 \\
\hline Can motivate students to study & 47 & 45 & 92 & 83.64 \\
\hline Easy for students to understand & 47 & 46 & 93 & 84.55 \\
\hline Encourage students to read other references & 48 & 46 & 94 & 85.45 \\
\hline Use correct Indonesian & 50 & 48 & 98 & 89.09 \\
\hline Use clear and simple sentences & 48 & 49 & 97 & 88.18 \\
\hline Illustration of attractive images and colors & 47 & 49 & 96 & 87.27 \\
\hline Image illustrations represent the message conveyed & 45 & 53 & 98 & 89.09 \\
\hline Total & & & 2582 & \\
\hline
\end{tabular}

Note: The maximum score for each aspect evaluated is 110 . The maximum overall score for content validation is 2860

The results of the evaluation of the module content validators that have been developed refer to the requirements for developing a good module that is writing the contents of the material framework is appropriate can lead the reader to a general description of the material in the module, preliminary writing has led the reader to the purpose of the module, the learning objectives are right, a matter of practice and the answer key is appropriate as an evaluation tool, measures the achievement of objectives, and a proper summary summarizes the material and draws the reader's attention. Learning instructions can be categorized as being able to give signs to the reader so that it makes it easier to learn modules, adequate reading resources as a basis for further development for the reader. All sections are well identified, pages and exercises are numbered completely, type and font size and physical size of the module is appropriate for the size of the student, the existing illustrations can attract students' attention in learning the module.

From this point of view it is stated that the elaboration of the material for each module is generally in accordance with the curriculum, objectives, learning flow. In addition, each module has a link/relationship, and the module in general can motivate students to learn. The results of the validators' evaluation of the elaboration of the module material are correct and can be used with a little revision. In terms of language use and illustrations in the module, that the language used is easily understood by students, the use of language is appropriate and the pictures / illustrations in the module are also appropriate. The results of the validators' assessment of language use and illustrations/ drawings in the module are correct and can be used with a little revision.

The total score of the content validation questionnaire assessment by the validators are 
2582. Based on the total score included in the interval class (2289-2860), the overall content validity of the module including the criteria is very valid.

\section{Test Results of Students}

A small group test was conducted on six students of IAIN Padangsidimpuan from PGMI department who had different levels of ability. The results of tests in this small group did not get too many revisions. Revisions given by students tend to improve the writing format, namely writing sentences whose letters are incomplete, spaces between sentences that vary, and the ordering of numbers is not right yet.After the module has been tested in small groups, the module is then revised. Based on the revised results, the module was retested on a group of students in a limited test. The number of test subjects was 25 students of IAIN Padangsidimpuan from PGMI department. The test results give few revisions and are almost the same as small group tests. For students who are classified as smart groups provide a very good revision that is an improvement on the key answers that deviate/miscalculated.

\section{Practicality of Statistics Module}

To see the practicality of learning tools used in the learning process is obtained through observation of the learning process, the impression of lecturers and students during the learning process. Observation data were obtained by filling in an open observation sheet/ field note, while interviews were obtained from lecturers and students.

The results of observations on the implementation of the module learning process

To see whether the use of modules in the learning process can be said to be practical, an observer is observed. Observations were made on the ease of lecturers and students in using and understanding modules. Based on observations as outlined in the observer in the field notes/ open observation sheet obtained the information that the use of statistical modules can be said to be practical. Students and lecturers can easily use modules. Students who find difficulty in using and understanding modules are students with low levels of ability. The average difficulty they get is in completing/understanding the examples and practice questions provided.

\section{Results of Interviews with Lecturers}

The lecturers Interviews are conducted after the implementation of the learning process. The purpose of the interview is to find out how far the implementation of the learning process using modules has been carried out and to find out the usefulness of the learning tools. In general the results of interviews obtained from lecturers stated that the statistical module used was practical. Only the timing is not yet certain because it depends on the speed and ability of students. In the opinion of the lecturer, if the ability of students who are taught to have good abilities of course learning with modules will be more optimal results.

\section{Results of Interviews with Students}

In general, interviews were obtained from students that the modules used in the learning process were already practical. The results of interviews with three groups of different abilities showed that the speed in understanding the modules and working on the exercise questions of opinion differed according to their abilities.

\section{Results of Module Prototype Practicality}

After observing the implementation of the learning process using modules, the results of observations, interviews with lecturers and students, it can be concluded about the practicality of the learning prototype. For observer assessment of the practicality of learning can be shown in the following Diagram 1: 


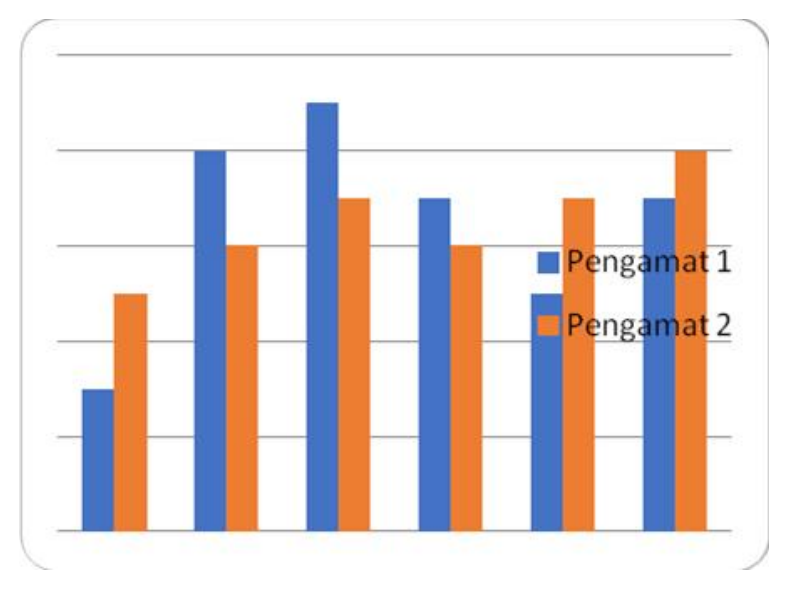

Diagram 1. Data on the Practicality of Statistics Module

Note:Score 1= Very Deficient

Score 2= Deficient

Score 3 = fairly Good

Score $4=$ Good

Score $5=$ Good

In general, assessors think that the use of statistical learning modules as a whole is very practical to use. However, the module still has a few revisions after a limited trial was conducted.

\section{The Effectiveness of the Statistics Module}

The assessment phase is to see the effectiveness of the module. The observed effectiveness is the implementation of the learning process with modules, the results of interviews with lecturers and students, and student learning outcomes.

\section{Observation results on the implementation of the learning process}

To see whether the implementation of the learning process using modules has been carried out in accordance with the principles of learning the module, the learning process is observed by two observers. Observations were made on the learning process, classroom situations, interactions that occur, student motivation in general, lecturer and student activities. The results of observations on the implementation of the learning process can be seen in table 6 below.

Table 6.Observation Result Data on Learning Process Using Statistics Module

\begin{tabular}{|c|c|c|c|c|c|c|c|c|c|c|c|c|c|}
\hline \multirow{2}{*}{ No } & \multirow{2}{*}{ Observed aspects } & \multicolumn{10}{|c|}{ Meetings } & \multirow{2}{*}{ Total } & \multirow{2}{*}{ Mean } \\
\hline & & 1 & 2 & 3 & 4 & 5 & 6 & 7 & 8 & 9 & 10 & & \\
\hline 1 & $\begin{array}{l}\text { Created a class situation } \\
\text { that encourages students } \\
\text { to ask questions and } \\
\text { discuss with each other }\end{array}$ & 4 & 4 & 5 & 4 & 4 & 5 & 4 & 4 & 4 & 4 & 42 & 4.2 \\
\hline 2 & $\begin{array}{l}\text { Helping students } \\
\text { understand the entire } \\
\text { module }\end{array}$ & 4 & 4 & 4 & 5 & 5 & 4 & 5 & 4 & 4 & 4 & 43 & 4.3 \\
\hline 3 & $\begin{array}{l}\text { Motivate students during } \\
\text { the learning process }\end{array}$ & 3 & 4 & 4 & 4 & 4 & 5 & 5 & 4 & 4 & 5 & 42 & 4.2 \\
\hline 4 & $\begin{array}{l}\text { Stimulate students to state } \\
\text { their reasons for solving } \\
\text { problems in the module }\end{array}$ & 4 & 4 & 4 & 4 & 3 & 5 & 5 & 4 & 4 & 4 & 41 & 4.1 \\
\hline 5 & $\begin{array}{l}\text { Stimulate students to } \\
\text { develop independence in } \\
\text { understanding all modules }\end{array}$ & 4 & 5 & 4 & 4 & 5 & 5 & 4 & 4 & 5 & 4 & 44 & 4.4 \\
\hline
\end{tabular}

Note:

Score $1=$ Very Deficient

Score $2=$ Deficient

Score $3=$ fairly Good

Score $4=$ Good

Score 5 = Good

From Table 6 it can be seen that during the learning process the observers provide an average rating in the range of 3.5 to 4.67 . This means that the average learning process using 
modules is of good value. In conclusion the learning process by using the statistical module can create well the classroom situation that encourages students to ask each other questions, answer and express opinions, the occurrence of interaction between students, can motivate students to learn. In addition, learning by using the statistical module can stimulate students very well in developing independence and creativity in understanding modules and solving problems.

\section{The Results of the Interview with the Lecturers}

In general the results of interviews obtained from lecturers stated that the learning tool is a statistical module that is effective in increasing student learning activities and motivation.

\section{Results of Interviews with Students}

In general, interviews were obtained from students that the modules used in the learning process were effective in increasing student activity and motivation and independence. The results of interviews with three groups of different abilities showed that the speed in understanding the modules and working on the exercise questions of opinion differed according to their abilities.

\section{Learning outcomes}

Learning outcomes observed in this study are learning outcomes after completing using the module. To see the learning outcomes of students are given pre-test and post-test in the trial class. After being analyzed it was found that student learning outcomes were higher after using modules than before using modules. The following will be shown a description of the results of the pre-test and post-test.

Table 7. Comparison of pre-test and post-test scores

\begin{tabular}{lll}
\hline Description & Pre test & Post test \\
\hline The mean & 42,00 & 82,03 \\
Standard & 11,44 & 10,88 \\
Deviation & & \\
\hline
\end{tabular}

Based on the descriptive statistical analysis above it was found that the average post-test was higher than the pre-test average. Then, after the significance test was found that there were significant differences between the pre test and post test. This shows that the module developed is effective.

\section{Validity of Statistical Modules}

The Statistics Module is declared valid by the validators through the percentage of validation against several aspects observed, namely the appropriateness of content, the appropriateness of presentation, linguistic and contextual. This means that the contents of the design contained in the Statistics Module are good and complete according to the validator.

Based on the categories obtained from each of these aspects, the overall Statistics Module that is designed obtains a validity of 0.83 with a good category. This shows that the Statistics Module according to the validators has been declared good and can be used in the lecture process. The results of this study are in line with the results of the study conducted by Tjiptiany, et.al. (2016) which mentions a module that is otherwise valid is appropriate. Yani (2012) also mentioned that the results of the validation of the science module learning experts were declared eligible for use.

\section{Practicality of Statistics Module}

A good design should be practical. The criteria used to assess practicality in the development of this design are students' interest in learning activities, the material presented, and the ease of language used. During the implementation of learning using the Statistics Module design; in general the time provided is sufficient. The use of design can make it easier for students to understand lessons and solve problems related to their daily lives.

Furthermore, based on the observation sheet used during the learning process, all learning processes using the Statistics Module have been planned to run well at each meeting. Although there are some obstacles, it does not reduce the smooth learning process. Then, 
based on interviews with several students, it obtained good results. This can be seen from the students' interest in implementing learning activities and the instructions used in the presentation of the module are easy to understand, so students can understand statistical material well.

\section{The Effectiveness of the Statistics Module}

To see the effectiveness of the product, what was identified were the results of observations on the implementation of the learning process, the results of interviews with lecturers supporting subjects, the results of interviews with students, and student learning outcomes. Learning outcomes are the results of tests after learning. To see student learning outcomes given pre test before using the module and post test after using the module. After analyzing it was found that student learning outcomes were higher after using the statistical module than before using the statistical module. This shows that the statistical module developed is effective.

The results of this study are in line with the results of research by Marsan et al. (2016) and Yani (2012). Ajoke (2017) and Olumorin, et al. (2010) state that teaching materials are an important tool needed in the learning process for teaching efficiency and improving performance. In addition, Gusmania \& Pamungkas (2015); Hanggara \& Amelia (2018); Agustyaningrum \& Gusmania (2017); Maulydia, et.al. (2017); and (Marsan, 2016) state that the development of teaching materials has a positive impact in improving students' competency.

\section{CONCLUSION AND RECOMMENDATION}

The Statistics Module that has been developed has fulfilled the valid criteria in terms of the contents of the module, the principle of module development, and its characteristics. Validation aspects of this module include aspects of module organization, module writing format, description of the material, use of language and illustrations or pictures. The developed
Statistics Module meets practical criteria according to observers, lecturers, and students. This Statistics module is easy to use, has an interesting to learn, and is useful. In general, students enjoy lecturing using this module.

The developed Statistics Module meets the effective criteria. The effectiveness observed in this lecture is student learning outcomes. Student learning outcomes are higher after using modules compared to before using modules in lectures.

Based on the above research findings, the following recommendations need to be submitted that, first, the principles and procedures conducted in the development of this Statistics module can be used as a reference for lecturers in developing modules in other subjects. In developing modules, modifications can be made as long as they do not deviate from the principles and characteristics of module development. Second, this Statistics Module can be used as a reference for lecturers in the Statistics course.

\section{REFERENCES}

Agustyaningrum, Ni., \& Gusmania, Y. 2017. "Practicality And Effectiveness Of Geometry Analysis Module." Dimensi 6(3): 412-20.

Ajoke, A. R. 2017. "The Importance of Instructional Materials in Teaching English as a Second Language." International Journal of Humanities and Social Science Invention 6(9): 36-44.

Ashaari, N. S., Judi, H. M., \& Mohamed, H. 2011. "Student ' S Attitude towards Statistics Course." In Procedia Social and Behavioral Sciences 18(1): 287-94.

Daryanto. 2002. Menyusun Modul Bahan Ajar Untuk Persiapan Guru Dalam Mengajar. Yogyakarta: Gava Media.

Gusmania, Y., \& Pamungkas, T. 2015. "Pengembangan Modul Geometri Analitik Bidang Berbasis Contextual Teaching Learning (CTL) Untuk Meningkatkan Kompetensi Mahasiswa Universitas Riau Kepulauan (UNRIKA)." 
Dimensi 4(3): 1-11.

Hamdunah. 2016. "Development a Constructivist Module and WEb on Circle and Sphere Matherial With Wingeom Software." Journal on Mathematics Education 7(2): 109-16.

Hanggara, Y., \& Amelia, F. 2018. "Pengembangan Modul Statistik Pendidikan Berbasis CTL Untuk Meningkatkan Kompetensi Mahasiswa Universitas Riau Kepulauan Batam." PYTHAGORAS: Jurnal Pendidikan Matematika 7(2): 1-11.

Husna, A., \& Himmi, N. 2018. "Pengembangan Modul Berbasis Konstruktivisme Pada Mata Kuliah Analisis Vektor Di Unrika." PYTHAGORAS: Jurnal Pendidikan Matematika 7(2): 12-21.

Johnson, Elaine B. 2008. Contextual Teaching \& Learning. Bandung: MLC.

Joni, T.R,\& Wardhani, I.G.A.k. 1984. Pengembangan Paket Belajar. Jakarta: Depdikbud, P2LPTK.

Marsan, Linssay A. 2016. "The Impact of an Interactive Statistics Module on Novices' Development of Scientific Process Skills an Attitudes in a First-Semester Research Foundations Course." Journal of Microbiology \& Biology Education 17(3): 436-43.

Maulydia, S. S., Surya, E., \& Syahputra, E. 2017. "The Development Of Mathematic Teaching Material Through Realistic Mathematics Education To Increase Mathematical Problem Solving." International Journal Of Advance Research And Innovative Ideas In Education 3(2): 2962-71.

Muttaqin. 2017. "Design Research on Ratio and Proportion Learning by Using Ratio Table and Graph With Oku Timur Context at The 7th Grade." Journal on Mathematics Education 8(2): 211-22.

Nizar. 2018. "Developing PISA-Like Mathematics Problem Using The 2018
ASIAN Games Football and Table Tennis Context." Journal on Mathematics Education 9(2): 183-94.

Olumorin, C. O. 2010. "Development of Instructional Materials from Local Resources for Art-Based Courses." Asian Journal of Information Technology 9(2): 107-10.

Parmin, E. Peniati. 2012. "Pengembangan Modul Mata Kuliah Strategi Belajar Mengajar IPA Berbasis Hasil Penelitian Pembelajaran." Jurnal Pendidikan IPA Indonesia 1(1): 8-15.

Prastowo, Andi. 2010. Panduan Kreatif Membuat Bahan Ajar Inovatif. Yogyakarta: Diva Press.

Purwanto. 2007. Pengembangan Modul. Jakarta: Departemen Pendidikan Nasional Pusat Teknologi Informasi dan Komunikasi Pendidikan.

Sagita. 2018. "Developing Bilingual Scientific-Worksheet For Indefinite Integral." Journal on Mathematics Education 9(2): 249-58.

Slavin, RE. 1994. Educational Psychology: Theory and Practice. Boston: Allyn and Bacon.

Tjiptiany, Endang Novita. 2016. "Pengembangan Modul Pembelajaran Mateatika Dengan Pendekatan Inkuiri Untuk Membantu Siswa Kelas X Dalam Memahami Materi Peluang." Jurnal Pendidikan: Teori, Penelitian dan Pengembangan 1(10): 1938-42.

Yani, R. 2012. "Pengembangan Instrumen Dan Bahan Ajar Untuk Meningkatkan Kemampuan Komunikasi, Penalaran Dan Koneksi Matematis Dalam Konsep Integral." Penelitian Pendidikan 13(1): 44-52.

Yansen. 2019. "Developing PISA-Like Mathematics Problems on Uncertainty and Data Using ASIAN GAMES Football Context." Journal on Mathematics Educataion 10(1): 37-46. 